\title{
The Effect of Inflation, Interest Rates and Exchange Rates on Stock Prices of Manufacturing Companies in Basic and Chemical Industrial Sectors on the Indonesia Stock Exchange (IDX)
}

\author{
Jefry \& Abid Djazuli \\ Universitas Muhammadiyah Palembang, Indonesia \\ Email: abid.djazuli01@gmail.com
}

\begin{abstract}
This study examines the effect of inflation, interest rates and exchange rates on stocks in basic industrial sector and chemical manufacturing companies on the Indonesia Stock Exchange (BEI). The study period is 2013 to 2017. An ordinary least square (OLS) is employed. The results show that (1) There is a significant effect of inflation, interest rates and exchange rates on stocks. together with the Basic Industry and Chemical Sector Manufacturing companies on the Indonesia Stock Exchange (IDX); (2) There is a significant influence of inflation on shares in manufacturing companies in the Basic Industry and Chemical Sector on the Indonesia Stock Exchange (BEI); (3) There is no significant effect of interest rates on stocks in basic industrial sector and chemical manufacturing companies on the Indonesia Stock Exchange (BEI); (4) There is no significant effect of Exchange Rates on Shares in Basic Industry and Chemical Manufacturing companies on the Indonesia Stock Exchange (IDX).
\end{abstract}

Keywords: inflation, interest rate, exchange rate, stock price, Indonesia Stock Exchange

\section{Introduction}

The economy in Indonesia has experienced rapid growth from time to time. This growth is in line with the era of economic globalization faced by the world community. Economic growth will result in changes in the value of people's lives, patterns of life, patterns of thinking, behavior, which have the hope of a better community welfare. Today's society has an increasing desire to invest their funds, either in the form of shares, deposits or in other forms of investment. Basically, investing is the placement of a number of funds at this time to expect returns that will occur in the future.

In this modern economic era, companies really need additional capital to boost their operational performance. One of the companies obtaining capital is by offering ownership of the company to the public (Go Public) in the capital market. Stock investment is a type of investment that is quite high risk, so investors are required to make the right decision to invest their shares so that investors can get the return as expected. The results of investors' decisions in determining profitable investments are influenced by the ability of investors to understand and predict macroeconomic conditions in the future.

Stocks are one of the capital market instruments that investors are interested in. Every company that goes public must issue shares that can be owned by every investor. However, stock prices are very volatile and change from time to time. Price fluctuations depend on the strength of supply and demand, if a stock is in excess of demand, the share price will tend to rise, and vice versa if there is excess supply, the stock price tends to fall.

Price fluctuation in the stock market is a systematic risk that investors must face. Systematic

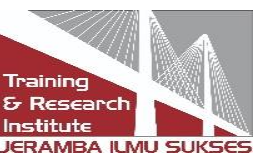


risk is uncontrollable because it relates to changes arising from fundamental macroeconomic factors and is capable of affecting the capital market and the country's economy. Investors must pay close attention to macroeconomic conditions, because this factor is one of various important external factors that can influence the company. Tandelilin (2014) suggests that the fluctuations that occur in the capital market are related to changes that occur in various macroeconomic variables.

An investor in carrying out stock trading activities in a country must pay attention to the monetary situation and movements of macroeconomic variables such as interest rates, exchange rates and inflation. Because domestic macroeconomic indicators that often influence stock price movements are fluctuations in currency exchange rates, inflation and interest rates.

Very high inflation can disrupt the economy in general because in addition to reducing purchasing power, the decline in the value of the currency can also increase the risk of decreasing people's real income. In investing, high inflation causes investors to be more careful in choosing and making transactions, so that investors tend to wait to invest until the economic situation is conducive to avoid the risks that may be caused by high inflation.

Interest rates have a very strong influence on the capital market (Manurung, 2009). The interest rate for Bank Indonesia Certificates (SBI) is a financial instrument issued by Bank Indonesia (BI) to control the circulation of money in the public by using the SBI interest rate reference. Changes in interest rates will subsequently affect a person's desire to make an investment, because in general changes in the SBI interest rate can influencing deposit rates and credit interest rates in the community, (Amin, 2012). If the deposit interest rate increases, investors tend to invest in the form of deposits because it can produce large returns with less risk and vice versa.

Companies in Indonesia pay great attention to information on the rupiah exchange rate or the exchange rate against the US dollar, because companies in Indonesia tend to use US dollars to make payments for production materials and other business transactions. The exchange rate of the rupiah against other currencies has an effect on a company's profit, because companies that use production materials from abroad will experience an increase in debt value. If the value of the rupiah against foreign currencies decreases or depreciates, the exchange rate is also very influential for companies wishing to invest, because if the foreign exchange market is more attractive than the capital market, investors will generally switch to investing in the foreign exchange market, therefore changes in exchange rates will affect the stock price in the capital market. 
Figure 1. Movement of the Composite Stock Price Index and Sectoral Index in 2012 - 2017

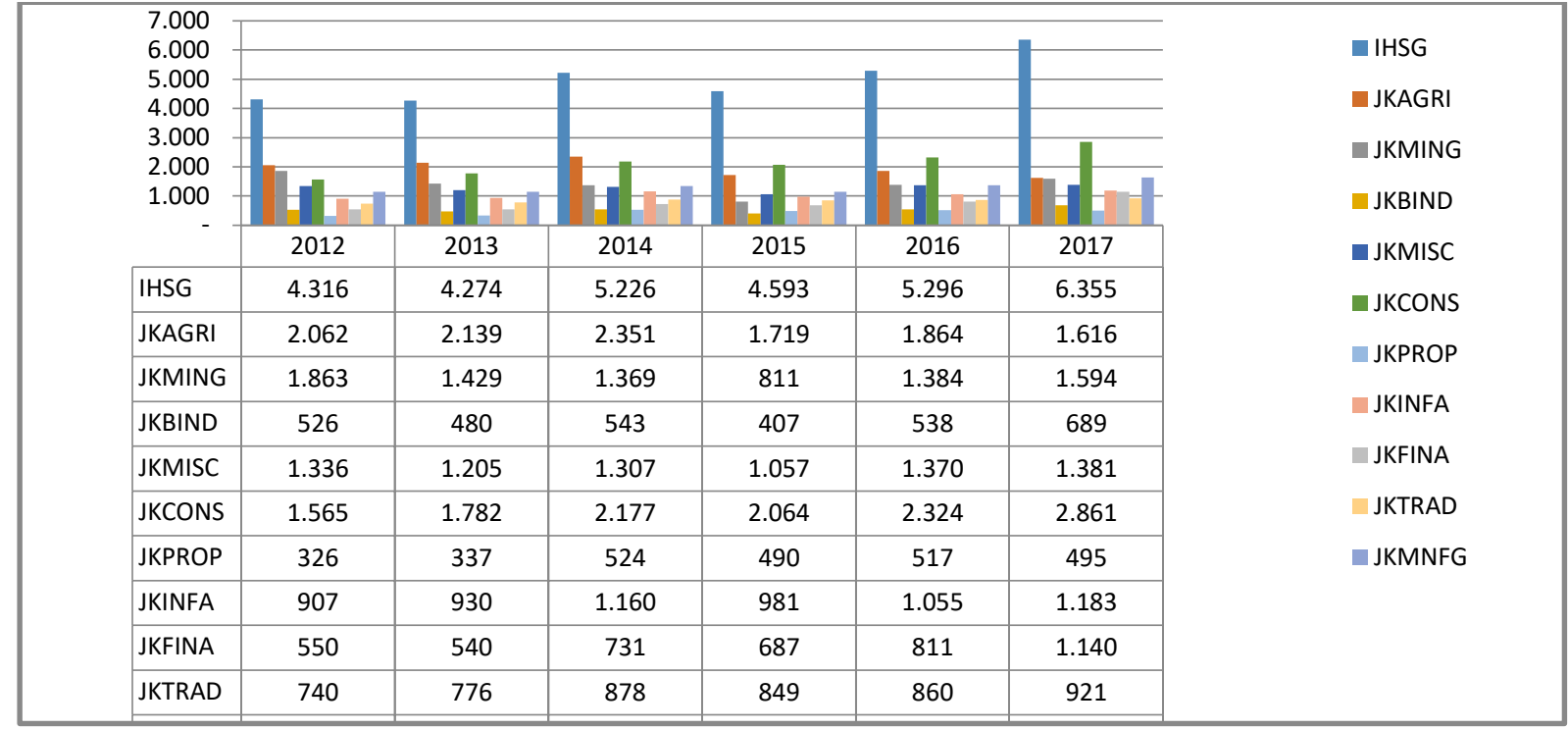

Source: investing.com, 2018

The image above shows the movements of the ten sectoral indices and the composite stock price index (IHSG). The movements and growth that occur in the composite stock price index (IHSG) are sometimes inversely related to sectoral indices, not all sectoral indices move in one direction with the composite stock price index (IHSG). Inflation can be defined as the general and continuous increase in prices for products and services. Every country must experience inflation, it's just that the difference is the rate of inflation it experiences. The following is the inflation rate experienced by Indonesia.

Figure 2. Inflation in $2012-2017$

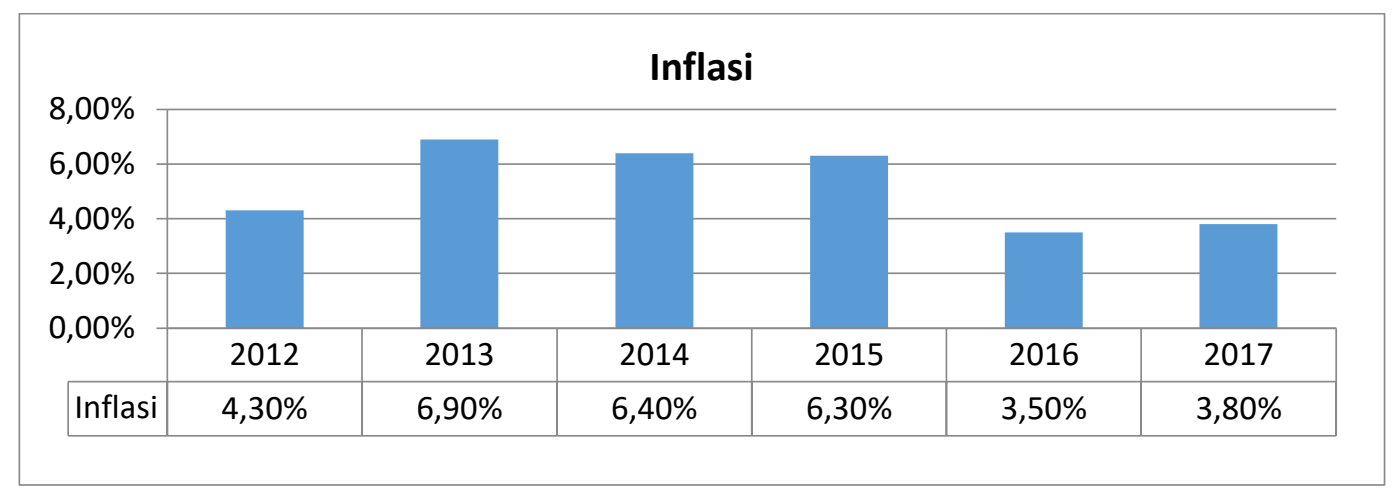

Source: BPS, 2018

The picture above shows the fluctuation of inflation in 2012 to 2016, in general it can be seen that the largest inflation rate occurred in 2013 at $6.90 \%$, but in the following year inflation began to decline to the smallest figure, namely $3.50 \%$ in 2016, In 2017, inflation experienced a rise again of $3.80 \%$, but the increase did not seem too significant

Inflation also has the impact of increasing interest rates. The benchmark interest rate is the SBI rate issued by Bank Indonesia. The following is data on SBI interest rates: 
Figure 3. Interest rates for $2012-2017$

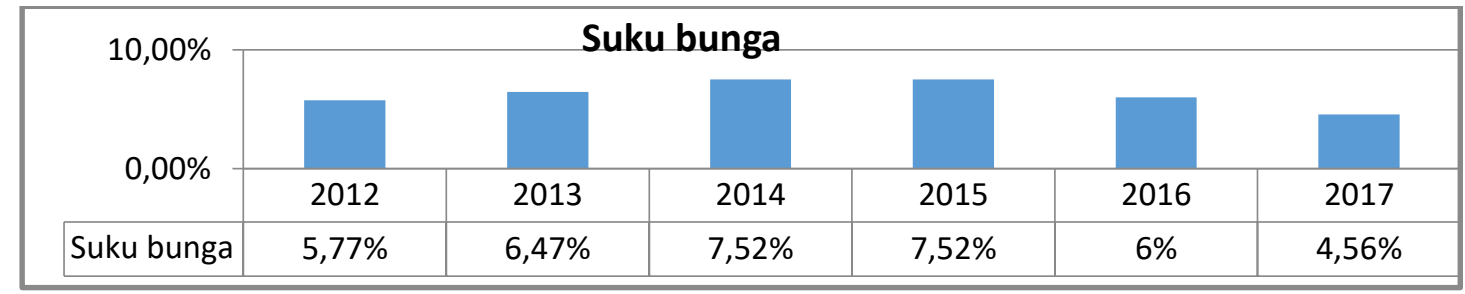

Source: bi.go.id, 2018

From the picture above, it can be seen that the SBI interest rate from 2012 to 2015 continued to increase, namely $5.77 \%, 6.47 \% 7.52 \%, 7.52 \%$ respectively, but in 2016 interest rates began to decline which is $6 \%$ and in 2017 decreased by $4.56 \%$, this is the smallest number of the last six years. Exchange rate (Kurs) is a relative price

Figure 4. Exchange Rates 2012 - 2017

\begin{tabular}{|c|c|c|c|c|c|c|}
\hline \multirow[t]{2}{*}{20.000} & \multicolumn{5}{|c|}{ Kurs } & \\
\hline & 2012 & 2013 & 2014 & 2015 & 2016 & 2017 \\
\hline Kurs & 9.511 & 10.520 & 12.091 & 13.641 & 13.491 & 13.462 \\
\hline
\end{tabular}

Source: bi.go.id, 2018

According to the picture above, it can be seen that the development of the rupiah exchange rate (Kurs) 2012 was Rp. 9,511 which is the smallest number, the highest exchange rate occurred in 2015, namely up to Rp. 13,641 at the end of 2015, while in 2016 and 2017 there was a decline again of Rp. 13,491 and Rp. 13,462.

\section{Literature Review}

According to Alwi (2008) there are several factors that influence the movement of stock prices or the stock price index, namely internal factors and external factors. Internal or micro environmental factors consist of (1) Announcements about marketing, production, sales such as advertising, contract details, price changes, new product recall, production reports, product safety reports and sales reports; (2) financing announcements, such as announcements related to equity and debt; (3) Announcement of management-board of director announcements, such as changes and changes in directors, management and organizational structure; (4) Announcement of takeover of diversification, such as reports of mergers, equity investments, reports of takeover by acquisitions, divestment reports and others; (5) Investment annuncements, such as conducting factory expansion, research development and other business closings; (6) Labor announcements, such as new negotiations, new contracts, strikes and others; (7) Announcement of company financial reports, such as forecasting earnings before the end of the year and after the end of the year, earnings per share (EPS), dividends per share (DPS), price earning ratios, net profit margins and return on assets (ROA).

External factors or the macro environment consist of (1) announcements from the government such as changes in savings and time deposit rates, foreign exchange rates, inflation, as well as various economic regulations and deregulations issued by the government; (2) Legal announcements, such as claims by employees against the company or against their managers 
and claims by companies against their managers; (3) Securities industry announcements, such as annual meeting reports, insider trading, trading share volume or price, trading restrictions / postponements; (4) Domestic political turmoil and exchange rate fluctuations are also factors that have a significant effect on stock price movements on a country's stock exchange.

According to Brigham and Houston (2006) the factors that influence interest rates are inflation, central bank policy, deficit or surplus in the state budget, international factors including the foreign trade balance and interest rates from other countries and the level of business activity. .

The benchmark interest rate is the Bank Indonesia Certificate (SBI) interest rate. The SBI interest rate is a policy interest rate that reflects the monetary policy stance set by Bank Indonesia and announced to the public.

SBI interest rates are announced by the Board of Governors of Bank Indonesia at every monthly Board of Governors Meeting and implemented in the monetary operations conducted by Bank Indonesia through liquidity management in the money market to achieve the operational targets of monetary policy. The operational targets for monetary policy are reflected in developments in the Interbank Overnight Money Market (PUAB O / N) interest rates. It is hoped that the movement in the interbank money market rate will be followed by developments in deposit rates and in turn bank lending rates.

Taking into account other factors in the economy, Bank Indonesia will generally raise the SBI interest rate if future inflation is expected to exceed the target set otherwise Bank Indonesia will lower the SBI interest rate if future inflation is estimated to be below the set target (www .bi.go.id).

According to Samsul (2015), an increase in interest rates has a negative impact on each issuer because it will increase credit interest expenses and reduce net income. A decrease in net income will result in a decrease in earnings per share and ultimately the share price to fall.

In general, it can be said that the lower the interest rate, the increase in economic growth because the intensity of the flow of funds will increase. If interest rates are high, automatically people will prefer to keep their funds in the bank because they can expect a favorable return. And in this position, the public's demand for holding cash is lower because they are busy allocating it into banking portfolios (deposits and savings). As the money supply decreases, the desire to spend will decrease. Furthermore, prices for goods and services generally tend to be stagnant or there is no push for inflation. Conversely, if the interest rate is low, the public will be less likely to be interested in saving their money in the bank.

Research conducted by Gede Sanjaya Adi Putra and P. Dyan Yaniartha (2014) with the title Effect of Leverage, Inflation and GDP on Stock Prices of Insurance Companies. The results of his research are Debt to Equity Ratio and Inflation Rate have a negative effect on stock prices of insurance companies listed on the IDX, growth in Gross Domestic Product has a positive and significant effect on stock prices of insurance companies listed on the IDX.

Research conducted by Yulia Efni (2013) entitled The Effect of Deposit Interest Rates, SBI, Exchange Rates and Infation on Stock Prices of Real Estate and Property companies on the IDX. The results of his research are that the interest rate deposits, SBI and inflation have an effect on stock prices, while exchange rates have no effect on stock prices of Real Estate and Property companies on the IDX.

Research conducted by Eri Saputra and Bambang Hadi Santoso (2017) with the title: The Effect 
of Currency Exchange Rates, Inflation, and Interest Rates on the Property Sector Stock Prices listed on the Indonesia Stock Exchange (IDX). The study population was 48 property companies with a sample of 10 companies (purposive sampling method based on predetermined criteria). The data analysis method uses multiple linear regression. The results showed that the exchange rate, inflation and interest rates together have a significant effect on stock prices. Partially it shows that currency exchange rates and inflation have a significant effect on stock prices, while interest rates have no effect.

Research conducted by Nurwanti (2017) entitled Analsis of the Effect of Inflation, Rupiah Exchange Rates, and SBI Interest Rates on the Movement of the Composite Stock Price Index on the Indonesia Stock Exchange. Secondary data for the quarterly period March 2007-March 2015. The results of inflation data processing have a negative and insignificant effect on the Composite Stock Price Index. The Rupiah exchange rate has a positive and significant effect on the Composite Stock Price Index. The interest rate on Bank Indonesia Certificates has a negative and significant effect on the Composite Stock Price Index. The fourth result of this study shows that inflation, the exchange rate of the rupiah, the interest rate of Bank Indonesia certificates have a significant influence simultaneously on the Composite Stock Price Index.

Research conducted by Umi Mardiyati and Ayi Rosalina (2013) with the title Effect of Exchange Rates, Interest Rates and Inflation on Stock Price Index Case Studies in Property Sector Companies in the Indonesia Stock Exchange. The population in this research is companies that are members of the property sector on the Indonesia Stock Exchange (BEI) for the period 2007-2011. The sample obtained using purposive sampling method to get 48 companies. His research uses Ordinary Least Square analysis to determine the effect of the independent variable on the stock price index of the property sector listed on the Indonesia Stock Exchange. Based on the $t$ test, the exchange rate has a significant negative effect on the property sector stock price index, while the interest rate variable is positive but not significant and the variable is positive but not significant on the property sector stock price index. The results simultaneously with the $\mathrm{F}$ test show that all independent variables have a significant effect on the property sector stock price index. So that only the exchange rate has an influence on the stock price index of the property sector listed on the Indonesia Stock Exchange.

\section{Research Method}

The research design used in this study is an associative research design because the research carried out aims to determine the influence or relationship between two or more variables, namely seeing the effect of inflation, interest rates and exchange rates on stock prices of basic and chemical manufacturing companies on the Stock Exchange. Indonesia (IDX).

Sources of data used in this study are secondary data in the form of annual financial reports and data on inflation, interest rates, exchange rates and stock prices in manufacturing companies in the Basic Industry and Chemical Sector on the Indonesia Stock Exchange (IDX) from 2012 to 2017. Types of data The data used in this research is panel data that combines time series data and data collection techniques used cross section data. 
Table 1. Variable Operationalization

\begin{tabular}{|c|c|c|c|c|}
\hline No & Variable & Definition & Indicator & Scale \\
\hline 1 & $\begin{array}{l}\text { Stock price } \\
\text { (Y) }\end{array}$ & $\begin{array}{l}\text { The share price is the price of a share that } \\
\text { occurs on the stock exchange at a certain } \\
\text { time determined by market players and } \\
\text { determined by the demand and supply of } \\
\text { shares in question on the capital market. }\end{array}$ & $\begin{array}{l}\text { End of month closing } \\
\text { stock price for the } \\
\text { period 2012-2017 }\end{array}$ & Ratio \\
\hline 2 & Inflation (X1) & $\begin{array}{l}\text { Inflation is a process of increasing prices } \\
\text { prevailing in an economy. }\end{array}$ & $\begin{array}{l}\text { Inflation } \\
(\%)\end{array}$ & Ratio \\
\hline 3 & $\begin{array}{l}\text { Interest rate } \\
\text { (SBI) } \\
(\mathrm{X} 2)\end{array}$ & $\begin{array}{l}\text { The SBI interest rate is the interest rate } \\
\text { issued by Bank Indonesia (BI) on the } \\
\text { issuance of Bank Indonesia Certificates } \\
\text { (SBI) }\end{array}$ & Interest rate $(\%)$ & Ratio \\
\hline 4 & $\begin{array}{l}\text { Exchange rate } \\
\text { (kurs) } \\
\text { (X3) }\end{array}$ & $\begin{array}{l}\text { The rupiah exchange rate is the value of } \\
\text { one rupiah currency which is translated into } \\
\text { the currency of another country. }\end{array}$ & $\begin{array}{l}\text { Average exchange rates } \\
\text { per year for the } 2012- \\
2017 \text { period }\end{array}$ & Ratio \\
\hline
\end{tabular}

The Basic Industry and Chemical Sector Index (JKBIND) is an index that describes the movement of shares in basic industrial and chemical sector companies listed on the Indonesia Stock Exchange (IDX) and stocks in the basic industrial sector and chemicals are divided into several sub-sectors, namely (1) Cement subsector; (2) ceramic, porcelain and glass subsectors; (3) Metal subsector and the like; (4) Chemical subsector

The population in this study were all 13 (thirteen) Plastics and Packaging Sub Sector Manufacturing companies consisting of:

Table 2. Total Population

\begin{tabular}{|l|l|l|}
\hline No: & Code & Company name \\
\hline 1 & AKKU & Alam Karya Unggul, Tbk \\
\hline 2 & AKPI & Argha Karya Prima Industy, Tbk \\
\hline 3 & APLI & Asiaplant Industry, Tbk \\
\hline 4 & BRNA & Berlina, Tbs \\
\hline 5 & FPNI & $\begin{array}{l}\text { Lotte Chemical Titan, Tbk d.h Titan Kimia Nusantara, Tbk d.h Fatra } \\
\text { Folindo Nusa Industri, Tbk }\end{array}$ \\
\hline 6 & IGAR & Champion Pasific Indonesia, Tbk d.h Kogeo Igar Jaya, Tbk \\
\hline 7 & IMPC & Impack Pratama Industri, Tbk \\
\hline 8 & IPOL & Indopoly Swakarsa Industri, Tbk \\
\hline
\end{tabular}




\begin{tabular}{|l|l|l|}
\hline 9 & SIAP & Sekawan Inti Pratama, Tbk \\
\hline 10 & SIMA & Siwani Makmur, Tbk \\
\hline 11 & TALF & Tunas Alfin, Tbk \\
\hline 12 & TRST & Trias Sentosa, Tbk \\
\hline 13 & YPAS & Yana Prima Hasta Persada, Tbk \\
\hline
\end{tabular}

According to Fauzi, Dencik and Asiati (2019), the sample is part of the number and characteristics of the population. If the population is large, and the research is not possible to learn everything that is in the population, for example, limited funds and time, then the researcher can use a sample taken from that population, the conclusions will be applicable to the population. For samples taken from the population must be truly reprensive (representative). Determination of the sample in this study using the following criteria: (1) Companies that remain listed on the Indonesia Stock Exchange during the study period, namely 2013-2017; (2) Companies that have the same asset value (total assets); (3) Companies that published complete and periodic financial reports during the research period, namely 2013-2017; (4) Companies that have complete data regarding information on share prices during the study period 20132017.

Based on the sample criteria above, it can be explained that there are 5 (five) companies, which during the 2013-2017 time period, their financial statements are incomplete, so these companies are not used as research samples, including: AKKU: Alam Karya Unggul, Tbk., SIMA: Siwani Makmur, Tbk., TALF: Tunas Alfin, Tbk., YPAS: Yana Prima Hasta Persada, Tbk., BRNA: Berlina, Tbk., So the sample in this study only consisted of 9 (nine) manufacturing companies. The Plastics and Packaging Sub-Sector listed on the Indonesia Stock Exchange for the 20132017 period, the sample list is as follows:

Table 3. Number of Samples

\begin{tabular}{|l|l|l|}
\hline No: & Code & Company name \\
\hline 1 & AKPI & Argha Karya Prima Industy, Tbk \\
\hline 2 & APLI & Asiaplant Industry, Tbk \\
\hline 3 & FPNI & $\begin{array}{l}\text { Lotte Chemical Titan, Tbk d.h Titan Kimia Nusantara, Tbk d.h Fatra } \\
\text { Folindo Nusa Industri, Tbk }\end{array}$ \\
\hline 4 & IGAR & Champion Pasific Indonesia, Tbk d.h Kogeo Igar Jaya, Tbk \\
\hline 5 & IMPC & Impack Pratama Industri, Tbk \\
\hline 6 & IPOL & Indopoly Swakarsa Industri, Tbk \\
\hline 7 & SIAP & Sekawan Inti Pratama, Tbk \\
\hline 8 & TRST & Trias Sentosa, Tbk \\
\hline
\end{tabular}


Regression analysis is used to determine the relationship between the dependent variable and the independent variable. If there is only one dependent and independent variable it is called simple regression analysis, if there are several independent variables it is called multiple regression analysis (Winarno, 2011, 4.1). The basic equation in this test is as follows:

$Y \_$it $1=a+b \_$it1 $X \_$it $1+b \_$it $2 X_{-}$it $2+b \_$it $3 X_{-}$it $3+\varepsilon \_$it

Where :

Y_it1 $=$ Share Price

$\mathrm{a}=$ Constant

b_it $1 . . . b \_$it5 $=$Regression Coefficient

X_it1 = Inflation

$\mathrm{X}$ _it $2=$ Interest Rate $(\mathrm{SBI})$

$\mathrm{X} \_$it3 = Exchange Rate (Exchange Rate)

$\varepsilon_{-}$it $=$Error of Term.

\section{Findings and Discussions}

This study aims to determine the effect of inflation, interest rates and exchange rates on stock prices of manufacturing companies in the basic industry and chemical sectors on the Indonesia Stock Exchange (BEI) in 2013-2017. This study uses secondary data in the form of financial reports of companies in the plastic and packaging sub-sector manufacturing. listed on the Indonesia Stock Exchange for the period 2013-2017

Based on data obtained from the IDX through its website www.idx.co.id, it is known that the population of this study is 13 (thirteen) Plastics and Packaging Sub-Sector Manufacturing companies. The sample in this study used certain considerations or criteria. The research period used was 5 years.

Based on the list of company names and using SPSS, the following descriptive statistics were obtained:

Table 4. Data Descriptive Statistics Test Results

\begin{tabular}{|l|l|l|l|}
\hline & Mean & Std. Deviation & $\mathrm{N}$ \\
\hline Saham & 3618.5714 & 2791.19705 & 7 \\
Inflasi & 3.7829 & 38196 & 7 \\
Sukubunga & 5.6429 & 1.08836 & 7 \\
Kurs & 11455.2857 & 1785.51036 & 7 \\
\hline
\end{tabular}

In the second data above on variable $\mathrm{Y}$, and variable $\mathrm{X}$, it is obtained a probability value $>$ $\square \square 0.05$, this means that the data on these variables have been normally distributed.

In the table above, the average inflation rate is 3.78 , the interest rate is 5.64 and the exchange rate is 11.445. As well as the standard deviation for all independent and dependent variables is 
3618.5 for stocks and 0.38 inflation variables, 1.08 interest rates, while 1785.5 in exchange rates.

Graph 1. Normal Q-Q plots test results

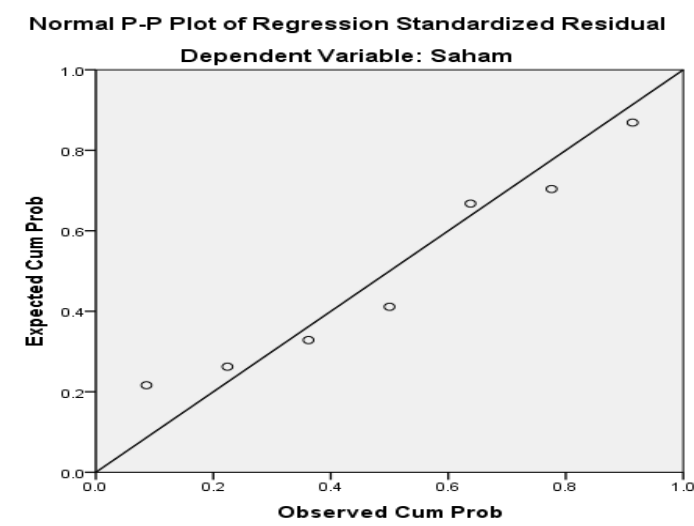

The diagonal lines in this graph represent the ideal state of the data following a normal distribution. The points around the line are the state of the data under test, if most of the points are very close to the line it can be concluded that the data follows a normal distribution.

Based on the available data, the following regression results were obtained:

Table 5. Multiple Linear Regression

\begin{tabular}{|c|c|c|c|c|c|c|c|c|c|c|}
\hline \multirow[t]{2}{*}{ Mode } & \multirow[t]{2}{*}{$\mathrm{R}$} & \multirow{2}{*}{$\begin{array}{l}\mathrm{R} \\
\text { Square }\end{array}$} & \multirow{2}{*}{$\begin{array}{l}\text { Adjusted R } \\
\text { Square }\end{array}$} & \multirow{2}{*}{$\begin{array}{l}\text { Std. } \\
\text { of } \\
\text { Estimate }\end{array}$} & \multicolumn{5}{|c|}{ Change Statistics } & \multirow{2}{*}{$\begin{array}{l}\text { Durbin- } \\
\text { Watson }\end{array}$} \\
\hline & & & & & $\begin{array}{l}\mathrm{R} \\
\text { Change }\end{array}$ & F Change & df1 & $\mathrm{df} 2$ & $\begin{array}{l}\text { Sig. } \\
\text { Change }\end{array}$ & \\
\hline 1 & $.937^{\mathrm{a}}$ & .878 & .756 & $\begin{array}{l}1379.9013 \\
6\end{array}$ & .878 & 7.183 & 3 & 3 & .070 & 1.673 \\
\hline
\end{tabular}

a. Predictors: (Constant), Kurs, Sukubunga, Inflasi

b. Dependent Variable: Saham

From the results of the regression output above, it is obtained by the following equation:

The R-square value is 0.878

The Adjusted R-square value is 0.756

F The statistic is 7,183

The probability of F Statistic is 0.70

Durbin Watson's value is 1,673

The multiple regression analysis model aims to predict the size of the dependent variable by using the data of the independent variables whose size is known (Santoso, 2010). Based on the analysis model that has been obtained above, it is necessary to test to determine whether the multiple linear regression model obtained meets the criteria.In the SPSS program it is carried out on the regression equation model, namely: 
Table 6. Regression Model Test Results

\begin{tabular}{|c|c|c|c|c|c|c|c|c|c|c|c|c|}
\hline \multirow[t]{2}{*}{ Model } & \multicolumn{2}{|c|}{$\begin{array}{l}\text { Unstandardized } \\
\text { Coefficients }\end{array}$} & \multirow{2}{*}{\begin{tabular}{|l} 
Standardiz \\
ed \\
Coefficien \\
ts \\
Beta
\end{tabular}} & & \multirow[t]{2}{*}{ Sig. } & \multicolumn{5}{|c|}{ 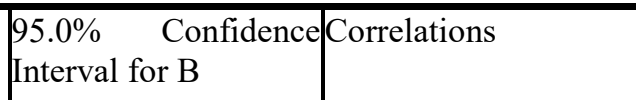 } & \multicolumn{2}{|c|}{$\begin{array}{l}\text { Collinearity } \\
\text { Statistics }\end{array}$} \\
\hline & $B$ & Std. Erro & & & & $\begin{array}{l}\text { Lower } \\
\text { Bound }\end{array}$ & $\begin{array}{l}\text { Upper } \\
\text { Bound }\end{array}$ & $\begin{array}{l}\text { Zero- } \\
\text { order }\end{array}$ & Partial & Part & \begin{tabular}{|l|} 
Toleran \\
ce
\end{tabular} & VIF \\
\hline (Constan & 58559.39 & 16722.81 & & 3.502 & .039 & 5339.944 & 111778.84 & & & & & \\
\hline & 3 & $\begin{array}{l}1 \\
3054.615\end{array}$ & -1.399 & -3.346 & .044 & & 2 & -.842 & -.888 & -.675 & .233 & 4.289 \\
\hline Inflasi & $\begin{array}{l}10221.24 \\
1\end{array}$ & & & & & 19942.388 & & & & & & \\
\hline $\begin{array}{l}\text { Sukubun } \\
\text { ga }\end{array}$ & -379.306 & 812.812 & -.148 & -.467 & .673 & -2966.035 & 2207.423 & -.647 & -.260 & -.094 & 406 & 2.466 \\
\hline Kurs & -1.234 & 607 & -.789 & -2.033 & .135 & -3.165 & .697 & .501 & -.761 & -.410 & .270 & 3.700 \\
\hline
\end{tabular}

a. Dependent Variable: Saham

The analysis used in this study uses multiple regression analysis of the regression equation:

$\mathrm{Y}=58,559.3+10,221,2 \mathrm{X} 1+379,3 \mathrm{X} 2+(-1,234) \mathrm{X} 3+\mathrm{e}$

Where :

$\mathrm{Y}=$ Shares

$\mathrm{a}=$ Constant

$\mathrm{X} 1=$ Inflation

$\mathrm{X} 2=$ Interest rate

$\mathrm{X} 3$ = Exchange rate

b1, b2, b3 = regression coefficient of each independent variable.

$\mathrm{e}=$ Error term

A regression model is declared free of multicollinearity if it has a tolerance value greater than 0.1 or a VIF value less than 10.From table 4.4 above, it is known that all variables in this study have a tolerance value greater than 0.1 and a VIF value on This research variable has a value less than 10. Thus it can be concluded that the data in the regression model is free from multicollonearity problems.

From the results of the heteroscedasticity test in the table above, it is known that the significance value of the interest rate and exchange rates variable has a significant value greater than 0.05 , this indicates that the interest rate and exchange rate are free from heteroscedasticity problems. Meanwhile, the significant inflation variable is smaller than 0.05 , this indicates that the inflation variable has a heteroscedasticity problem. 
Table 7. Autocorrelation test results

\begin{tabular}{|c|c|c|c|c|c|c|c|c|c|c|}
\hline \multirow[t]{2}{*}{ Mode } & \multirow[t]{2}{*}{$R$} & \multirow{2}{*}{$\begin{array}{l}\mathrm{R} \\
\text { Square }\end{array}$} & \multirow{2}{*}{$\begin{array}{l}\text { Adjusted } \\
\text { Square }\end{array}$} & \multirow{2}{*}{$\begin{array}{l}\text { R Std. Error } \\
\text { of the } \\
\text { Estimate }\end{array}$} & \multicolumn{5}{|c|}{ Change Statistics } & \multirow{2}{*}{ Durbin- } \\
\hline & & & & & $\begin{array}{l}\mathrm{R} \quad \text { Square } \\
\text { Change }\end{array}$ & F & df1 & df2 & $\begin{array}{l}\text { Sig. } \\
\text { Change }\end{array}$ & \\
\hline 1 & $.937^{\mathrm{a}}$ & .878 & .756 & 1379.90136 & .878 & 7.183 & 3 & 3 & .070 & 1.673 \\
\hline
\end{tabular}

a. Predictors: (Constant), Kurs, Sukubunga, Inflasi

b. Dependent Variable: Saham

Based on the regression output that has been done, it is obtained a DW value of 1.673 from two theories regarding autocorrelation testing, the following results are obtained:

According to Danang (2012) one measure in determining whether or not an autocorrelation problem is with the Durbin Watson exam with the following conditions:

If the DW value $<-2$, positive auto correlation occurs

If $-2<$ DW $<2$, no autocorrelation occurs.

If the DW value $>2$, negative autocorrelation occurs.

The test results on the autocorrelation problem using the application on the model get the results as in the table below:

In the model, the autocorrelation test results can be seen in the Durbin-Watson value which has a value of 1.821 , which is $-2<1.673<2$ meaning that Ho is accepted, meaning that the model does not have autocorrelation problems, so the data is suitable for prediction (Sunyoto, 2011: 91)

\section{Hypothesis testing}

\section{Test together (Test F)}

The $\mathrm{F}$ test is used to determine whether the independent variables jointly have an influence on the dependent variable. The basis for making decisions is:

H0: There is no effect of inflation, interest rates and currencies together on the Stock Price of Manufacturing Companies in the Basic Industry and Chemical Sector on the Indonesia Stock Exchange (BEI)

Ha: There is an effect of inflation, interest rates and dates together on the Stock Price of Manufacturing Companies in the Basic Industry and Chemical Sector on the Indonesia Stock Exchange (BEI)

Hypothesis criteria

If $\mathrm{F}$ count $\geqslant \mathrm{F}$ table or sig $\mathrm{F} \leqslant \alpha(0.05)$, then $\mathrm{H} 0$ is rejected and $\mathrm{Ha}$ is accepted, meaning that there is an effect of inflation, interest rates and currency jointly on the stock price of manufacturing companies in the basic industry and chemical sectors on the stock exchange. Indonesian Securities (IDX)

If $\mathrm{F}$ count $<\mathrm{F}$ table or sig $\mathrm{F}>\alpha(0.05)$, then $\mathrm{H} 0$ is accepted and $\mathrm{Ha}$ is rejected, meaning that there 
is no influence of inflation, interest rates and currency rates simultaneously on the Stock Price of Manufacturing Companies in the Basic Industry and Chemical Sector in Indonesia Stock Exchange (IDX)

Table 8. F Test Results

\begin{tabular}{|l|l|l|l|l|l|}
\hline Model & Sum of Squares & df & Mean Square & F & Sig. \\
\hline \multirow{2}{*}{$\begin{array}{l}\text { Regression } \\
1\end{array} \quad \begin{array}{l}\text { Residual } \\
\text { Total }\end{array}$} & 57032302.388 & 3 & 161.229 & 7.424 & $.043^{\mathrm{b}}$ \\
\hline
\end{tabular}

a. Dependent Variable: Saham

b. Predictors: (Constant), Kurs, Sukubunga, Inflasi

From the ANOVA or Ftest test, obtained Fcount is 7,424 with a significant level of 0.043 . F table 6.94 is obtained by looking at the $\mathrm{F}$ table with degrees $\mathrm{df}=\mathrm{k}-1(\mathrm{df}=3-1)$ and $\mathrm{df}=\mathrm{n}-1$ $(\mathrm{df}=5-1)$ at a significant level of 0.05 . Because the probability $(0.043)$ is smaller than 0.05 and Fcount $>$ Ftable, this shows that Ho is rejected and Ha is accepted or in other words there is an effect of inflation, interest rates and exchange rates simultaneously on the stock prices of manufacturing companies in the basic industrial sector. And Chemicals on the Indonesia Stock Exchange (IDX)

Partial Test ( $\mathrm{t}$ test)

The $t$ test is used to determine whether individually each independent variable in the study has an influence on the dependent variable in the study.

$\mathrm{H} 0$ : There is no effect of inflation, interest rates and exchange rates partially on the Stock Price of Manufacturing Companies in the Basic Industry and Chemical Sector on the Indonesia Stock Exchange (BEI)

Ha: There is an effect of inflation, interest rates and dates partially on the stock price of manufacturing companies in the basic industry and chemical sectors on the Indonesia Stock Exchange (BEI)

Hypothesis criteria

If $\mathrm{t}$ count $\geqslant \mathrm{t}$ table or sig $\mathrm{t} \leqslant \mathrm{a}(0.05)$, then $\mathrm{H} 0$ is rejected and $\mathrm{Ha}$ is accepted, meaning that there is an effect of inflation, interest rates and currency partially on the Stock Price of Manufacturing Companies in the Basic Industry and Chemical Sector on the Indonesia Stock Exchange (IDX)

If $\mathrm{t}$ count $<\mathrm{t}$ table or sig $\mathrm{t}>\alpha(0.05)$, then $\mathrm{H} 0$ is accepted and $\mathrm{Ha}$ is rejected, meaning that there is no effect of inflation, interest rates and currency are partially on the stock price of manufacturing companies in the basic industry and chemical sectors on the stock exchange. Indonesia (IDX) 
Table 9. $\mathrm{t}$ test results

\begin{tabular}{|l|l|l|l|}
\hline Variable & Coefficient & $\mathrm{T}$ & Prob. \\
\hline C & 58559.393 & 3.502 & .039 \\
\hline Inflasi & -10221.241 & 3.346 & .044 \\
\hline Suku bunga & -379.306 & .467 & .673 \\
\hline Kurs & -1.234 & 2.033 & .135 \\
\hline
\end{tabular}

The results of the t-test for the variable (X1) Inflation against Stocks (Y) shows a sig value of 0.044 , which means that the significance value is smaller than the probability value of 0.05 $(0.044<0.05)$ and tcount shows 3.346, which means that tcount $<$ ttable $(3.346>2.919)$.

Then the conclusion is Ho is accepted and $\mathrm{Ha}$ is rejected, so it can be said that the Inflation variable individually or partially has a positive and significant effect on stocks.

For the variable (X2) Interest Rates on Stocks (Y) shows a sig value of 0.673 , which means that the significance value is greater than the probability value of $0.05(0.673>0.05)$ and tcount shows 0.467 meaning that tcount $<$ ttable $(0.467<2.919)$. So the conclusion is that Ho is rejected and $\mathrm{Ha}$ is accepted, so it can be said that the interest rate variable individually or partially does not have a positive and significant effect on stocks.

As for the variable (X3) Exchange to Stocks (Y) shows the sig value of 0.135, which means that the significance value is smaller than the probability value of $0.05(0.135>0.05)$ and tcount shows 2.033 which means tcount $>$ ttable $(2.033<2.919)$. So the conclusion is that Ho is rejected and $\mathrm{Ha}$ is accepted, so it can be said that the exchange rate variable individually or partially does not have a positive and significant effect on Stock Returns.

Based on the results of this study, it is known that there is another significant effect of inflation, interest rates and exchange rates together on shares in manufacturing companies in the basic industry and chemical sectors on the Indonesia Stock Exchange (BEI).

And individually or partially the results of this study show that the Inflation variable individually or partially has a positive and significant effect on the Shares of Manufacturing Companies in the Basic Industry and Chemical Sector on the Indonesia Stock Exchange (IDX), the interest rate variable individually or partially does not have a positive effect. and is significant to the shares of basic industrial sector and chemical manufacturing companies in the Indonesia Stock Exchange (BEI). Meanwhile, the exchange rate variable individually or partially has a positive and significant effect on the stocks of basic industrial and chemical manufacturing companies in the Indonesia Stock Exchange (BEI).

The results of this study are in line with research conducted by Eri Saputra and Bambang Hadi Santoso (2017) with the title: The Effect of Currency Exchange Rates, Inflation, and Interest Rates on Stock Prices of the Property Sector listed on the Indonesia Stock Exchange (BEI). The study population was 48 property companies with a sample of 10 companies (purposive sampling method based on predetermined criteria). The data analysis method uses multiple linear regression. The results showed that the exchange rate, inflation and interest rates together have a significant effect on stock prices. Partially it shows that currency exchange rates and inflation have a significant effect on stock prices, while interest rates have no effect. 
Research conducted by Nurwanti (2017) entitled Analsis of the Effect of Inflation, Rupiah Exchange Rates, and SBI Interest Rates on the Movement of the Composite Stock Price Index on the Indonesia Stock Exchange. Secondary data for the quarterly period March 2007-March 2015. The results of inflation data processing have a negative and insignificant effect on the Composite Stock Price Index. The Rupiah exchange rate has a positive and significant effect on the Composite Stock Price Index. The interest rate on Bank Indonesia Certificates has a negative and significant effect on the Composite Stock Price Index. The fourth result of this study shows that inflation, the exchange rate of the rupiah, the interest rate of Bank Indonesia certificates have a significant influence simultaneously on the Composite Stock Price Index.

Research conducted by Umi Mardiyati and Ayi Rosalina (2013) with the title Effect of Exchange Rates, Interest Rates and Inflation on Stock Price Index Case Studies in Property Sector Companies in the Indonesia Stock Exchange. The population in this research is companies that are members of the property sector on the Indonesia Stock Exchange (BEI) for the period 2007-2011. The sample obtained using purposive sampling method to get 48 companies. His research uses Ordinary Least Square analysis to determine the effect of the independent variable on the stock price index of the property sector listed on the Indonesia Stock Exchange. Based on the $t$ test, the exchange rate has a significant negative effect on the property sector stock price index, while the interest rate variable is positive but not significant and the variable is positive but not significant on the property sector stock price index. The results simultaneously with the $\mathrm{F}$ test show that all independent variables have a significant effect on the property sector stock price index. So that only the exchange rate has an influence on the stock price index of the property sector listed on the Indonesia Stock Exchange

\section{Conclusion}

Based on the discussion of the results of research on the effect of inflation, interest rates and exchange rates on stocks in basic industrial sector and chemical manufacturing companies on the Indonesia Stock Exchange (BEI), it can be concluded that: (1) There is a significant effect of inflation, interest rates and exchange rates on stocks. together with the Basic Industry and Chemical Sector Manufacturing companies on the Indonesia Stock Exchange (IDX); (2) There is a significant influence of inflation on shares in manufacturing companies in the Basic Industry and Chemical Sector on the Indonesia Stock Exchange (BEI); (3) There is no significant effect of interest rates on stocks in basic industrial sector and chemical manufacturing companies on the Indonesia Stock Exchange (BEI); (4) There is no significant effect of Exchange Rates on Shares in Basic Industry and Chemical Manufacturing companies on the Indonesia Stock Exchange (IDX).

\section{References}

Alwi, I.Z. (2008). Pasar Modal Teori dan Aplikasi. Jakarta: Yayasan Pancur Siwah.

Brigham, \& Houston. (2006). Fundamental of Financial Management: Dasar-dasar manajemen Keuangan. Jakarta: Salemba Empat

Darmaji Tjiptono dan Hendy M Fakhruddin. (2012). Pasar Modal Indonesia Pendekatan Tanya Jawab, Edisi Kedua. Jakarta: Penerbit Salemba Empat.

Tandelilin, E. (2014). Portopfolio dan investasi. Yogyakarta: Penerbit Percetakan Kanisius

Saputra, E., \& Santoso, B. H. (2017). Pengaruh Nilai Tukar Mata Uang, Inflasi, Dan Suku Bunga terhadap Harga Saham Sektor Properti yang terdaftar Di Bursa Efek Indonesia (BEI). 
Jurnal Ilmu dan Riset Manajemen, 6(5).

Fahmi, I. (2014). Manajemen Keuangan Perusahaan dan Pasar Modal. Edisi Pertama, Jakarta: Mitra Wacana Media.

Fauzi, F., Dencik, A. B., \& Asiati, D. I. (2019). Metodologi Penelitian Untuk Manajemen dan Akuntansi. Jakarta: Salemba Empat.

Putera, G.S.A., \& Yaniartha, P.D. (2014). Pengaruh Leverage, Inflasi dan PDB pada Harga Saham Perusahaan Asuransi. Semarang, (http://journal.unnes.ac.id)

Horison Jr., Walter, T., Hongren, C.T., Thomas, C. W., \& Suwardy, T. (2011). Akuntansi Keuangan. (Edisi Kedelapan, Jilid 2). Jakarta: Erlangga

Jogiyanto, H. (2013). Teori Portopolio dan Analisis Investasi. Edisi Kesembilan. Yogyakarta: BPFE

Kasmir. (2014). Bank dan Lembaga Keuangan Lainnya. Jakarta: Penerbit PT Rajagrapindo Persada.

Kasmir. (2014). Analisis Laporan Keuangan. Jakarta: Penerbit PT Rajagrapindo Persada.

Mudrajad, K. (2012). Metode Kuantitatif Teori dan Aplikasi untuk Bisnis dan Ekonomi. Jakarta: Erlangga

Manurung, M., \& Rahardja, P. (2009). Uang, Perbankan, dan Ekonomi Moneter. Jakarta: PT. Raja Grafindo

Nopirin. (2012). Pengantar Ilmu Ekonomi Mikro Makro. Yogyakarta: BPFE

Nurwani. (2017). Analsis Pengaruh Inflasi, Nilai Tukar Rupiah, Dan Suku Bunga SBI Terhadap Pergerakan Indeks Harga Saham Gabungan Di Bursa Efek Indonesia.

Sukirno, S. (2014) Teori Pengantar Makroekonomi. Jakarta: Penerbit Erlangga

Samsul, M. (2015). Pasar Modal dan Manajemen Portofolio. Edisi 2. Jakarta: Erlangga

Sugiyono. (2014). Metodelogi Penelitian Bisnis. Bandung: Penerbit Alfabeta, Bandung.

Mardiyati, U., \& Rosalina, A. (2013). Pengaruh nilai tukar, tingkat suku bunga dan inflasi terhadap indeks harga saham studi kasus pada perusahaan sektor properti di Bursa Efek Indonesia. Jurnal Riset Manajemen Sains Indonesia (JRMSI), 4(1).

Widiatmojo, S. (2009). Pasar Modal Indonesia. Jakarta: Penerbit Ghalia Indonesia.

Yulia, E. (2013). Pengaruh Suku Bunga Deposito, SBI, Kurs dan Inflasi terhadap Harga Saham Perusahaan Real Estate dan Property di BEI. Yogyakarta, (http://journal.uny.ac.id)

\section{Copyrights}

Copyright for this article is retained by the author(s), with first publication rights granted to the journal.

This is an open-access article distributed under the terms and conditions of the Creative Commons Attribution license (http://creativecommons.org/licenses/by/4.0/) 